\title{
Correction to: Anti-migraine agents from an immunological point of view
}

\author{
Mushref Bakri Assas* (1)
}

\section{Correction to: J Transl Med (2021) 19:23} https://doi.org/10.1186/s12967-020-02681-6

Following publication of the original article [1], the author identified an error in the author name of Mushref Bakri Assas.

- The incorrect author name is: Bakri M. Assas

- The correct author name is: Mushref Bakri Assas

The author group has been updated above and the original article [1] has been corrected.

Published online: 09 August 2021
References

1. Assas MB. Anti-migraine agents from an immunological point of view. J Transl Med. 2021;19:23. https://doi.org/10.1186/s12967-020-02681-6.

\section{Publisher's Note}

Springer Nature remains neutral with regard to jurisdictional claims in published maps and institutional affiliations. 